\title{
EMPLOYMENT IMPACTS OF RENEWABLE ENERGY IN UE
}

\author{
Piotr Gradziuk, $\mathrm{PhD}^{1}$; Barbara Gradziuk, $\mathrm{PhD}^{2}$ \\ ${ }^{1}$ Institute of Rural and Agricultural Development, Polish Academy of Sciences \\ ${ }^{2}$ Faculty of Agrobioengineering, University of Life Sciences in Lublin
}

\begin{abstract}
In the world renewable energy sector, including large hydropower, employed 10.3 million people, directly and indirectly, in 2017. This represents an increase of 5.3\% over the number reported the previous year. The aim of the executed research is to determine the influence of harvesting renewable energy on the labour market in EU. Eurostat databases provided a source of empirical data concerning the amount of produced energy. The following sectors were considered: solid biofuels, biogas, liquid biofuels, geothermal, hydropower, municipal waste, solar photovoltaic, solar thermal, wind power and heat pumps. The research concerned 28 Member States of the EU between 2009 and 2016. Panel estimation was used as means of empirical indication of relations between the variables. The obtained models are adjusted to the empirical data, the rectified coefficient of determination equalled, depending on the sector, 0.828 (liquid biofuels) to 0.981 (solid biofuels). The analysed models show that throughout the examined period, the solar and wind power sectors were the ones that consumed the larger amount of work. As it was indicated above, these sectors are considered the most innovative and technologically advanced ones and thus, the employment rates seem to decreased in the shorter time.
\end{abstract}

Keywords: renewable energy sources, employment, panel estimation JEL codes: O13, P18, Q42, Q54, Q58

\section{INTRODUCTION}

The use of renewable energy provides many benefits on the global, regional and local scale. The improvement of the environment condition and the improvement of energy safety (Janssen, 2002; Li, 2005; Ölz, Sims and Kirchner, 2007; Valentine, 2011) are the most frequently highlighted ones. Distributed power prevents major disturbances in the event of power grid or power providers' failure. Moreover, such strategy minimises costs of constructing and using transmission lines, as well as enhances provision of power, especially to areas with poor power infrastructure.
The development of the use of renewable energy sources results in increased employment (Kammen, Kapadia and Fripp, 2004; Moreno and Lopez, 2008; Sidorczyk-Pietraszko, 2015). In the world renewable energy sector, including large hydropower, employed 10.3 million people, directly and indirectly, in 2017 . This represents an increase of $5.3 \%$ over the number reported the previous year (International Renewable Energy Agency, 2016). This observation provided motivation for increasing funding for renewable energy production time and again. The White Paper entitled 'Energy for the Future: Renewable Sources of Energy' (European Commission, 1997) states that

\footnotetext{
${ }^{1}$ Corresponding author: Nowy Świat 72,00-330 Warsaw, Poland, pgradziuk@irwirpan.waw.pl, +4822 8269436

${ }^{2}$ Corresponding author: Akademicka 13,20-033 Lublin, Poland, barbara.gradziuk@up.lublin.pl, +4881 4610061
} 
doubled share of the renewable energy in the total energy use in the EU may result in creation of 500-900 thousand of job positions. Similar data was presented in such documents as 'Roadmap to a Resource Efficient Europe' (European Commission, 2011b) or 'The Roadmap for Moving to a Competitive Low-carbon Economy in 2050' (European Commission, 2011a). Within the EU, research concerning the evaluation of effects of conducting a support policy in terms of renewable energy and the development of the RES technologies on the labour market has been conducted from the early 1990s in the framework of such projects as: ECOTEC (Research \& Consulting Ltd., 1995), ALTENER (European Commission, 2003) or EmployRES (Fraunhofer ISI et al., 2014). The net effect were estimated to amount to 545-656 thousand job positions, which is almost equal to the data included in the White Paper of 1997. According to the report drafted by Greenpeace, the net employment in Poland (considering changes in mining and conventional energy sources) shall increase by 155 thousand until 2020, comparing to 2010 (Greenpeace Polska, 2011). It is significant to mention that such working places are usually created in rural areas characterised by a high unemployment level and may be suitable for candidates with low qualifications. The importance of using RES, primarily bio-mas, for the labour market reflects Schumacher's (1981) views, namely that: 'working places should be created exactly where people currently leave, not in cities so places where people migrate to; the applied methods of creating such places should be simple in order to minimise the demand for high qualifications not only in the sector of direct production bud also in the sector of material supply, organisation system, financing, marketing, etc.; goods should be produced with locally produced materials and they should suit the needs of the local markets'.

\section{MATERIALS AND METHODS}

The paper presents results of the research aiming at the analysis of the influence of harvesting renewable energy on the labour market. The number of the working people (directly in the enterprises operating in the field of producing raw energy materials and energy from renewable sources, as well as providing equipment and services within this field) in relation to 1,000 tonnes of oil equivalent of the primary energy obtained in particular sectors of renewable energy sources was used as the performance indicator.

Information of power production were acquired from the Eurostat Database, while the number of the employed and the performance of the installed equipment were determined thanks to reports drafted by EurObserv'ER or International Renewable Energy Agency (2018). The following sectors were considered: solid biofuels, biogas, liquid biofuels, geothermal, hydropower, municipal waste, solar photovoltaic, solar thermal and wind power The research concerned 28 Member States of the EU between 2009 and 2016. Such a scope was established due to significant changes on the renewable energy market triggered by the Climate and Energy Package passed by the European Parliament and the Council of the European Union. In result, the balanced panel of the maximum number of 196 observations was acquired for each sector ${ }^{3}$. In order to empirically identify the relation between the variables, the following fixed specific effects power panel model was constructed:

$$
Y_{i t}=\alpha_{0} \cdot X_{i t}^{\alpha_{1}} e^{\gamma_{i}+\delta_{t}+\varepsilon_{i t}}
$$

where:

$Y_{i t}$ - employment measured by the number of people working in $i$ - this country in the year $t$ in the given RES sectors;

$X_{i t}$ - primary energy produced in $i$ - this country in the year $t$ (thous. toe);

$\alpha_{1}$ - flexibility of employment in relation to the primary energy produced in specific res sectors;

$\gamma_{i}-$ cross-sectional individual effect for $i-$ of this country;

$\delta_{t}$ - temporary individual effect for $t$ - of this year;

$\varepsilon_{i t}-$ random element;

$t=1,2, \ldots, n-$ number of years;

$t=1,2, \ldots, m-$ number of countries.

${ }^{3}$ In the case of some sectors, a smaller number of observations was analysed due to the lack of data. 
After completing a bilateral logarithm we obtain the fixed specific effects linear panel model:

$$
\ln Y_{i t}=\alpha_{0}+\alpha_{1} \ln X_{i t}+\gamma_{i}+\delta_{t}+\varepsilon_{i t}
$$

whose parameters were estimated through the panel least squares method.

The obtained economic models were verified. Their quality as well as accuracy of their specification were tested with such tools as the Hausman's test.

The study was a continuation of long-term analyses the preliminary results of which were published in 2017 (Gradziuk and Gradziuk, 2017a). This article provides the latest available estimates and calculations on renewable energy and jobs. New Data are principally for 2015-2016 and employment in the heat pump sector.

\section{DESCRIPTION OF THE RENEWABLE ENERGY SOURCES SECTOR IN THE EU}

The increase of share of using the RES in the EU is determined by its policy. The Climate and Energy Package (Directive 2009/28/EC) stipulates that the share of RES in the total gross energy use in 2020 shall reach $20 \%$. However, for the starting point in terms of renewable energy production and the ability to collect it are different among the member states, the EU defined bounding targets for each country - from
$10 \%$ for Malta to $49 \%$ for Sweden. The analysis of the fulfilment of these targets (31 December 2016) suggests that as for Belgium, France, Ireland, Luxembourg, Malta, the Netherlands, the Great Britain and, to a smaller degree, for Cyprus and Spain, the achievement of the established share of the renewable energy is in danger. On the other hand, Austria, Bulgaria, Croatia, the Czech Republic, Denmark, Estonia, Finland, Hungary, Italy, Latvia, Lithuania, Romania and Sweden have already fulfilled targets for 2020 (Fig. 1).

In 2016, Germany, France, Italy, Spain, the Great Britain and Sweden were the largest renewable energy producers (Fig. 2).

The structure of acquiring renewable energy in EU indicates that up until recently, the bio-mass was the most important source. As it is easily available and may be used in such processes as direct combustion (e.g. wood, straw, sewage sludge); transformation into liquid fuel (e.g. rapeseed oil ester, alcohol) or gas fuel (e.g. agricultural biogas, biogas from sewage treatment plants, waste gas). In comparison to photovoltaic power plants and wind farms, biomass is one of the RES which does not require the so-called hot backup in the system of power disposition. Such requirement provokes discussions on power and impedes key legislative processes concerning the development of renewable energy sources. Biomass is mainly used in heat engineering, electrical power engineering, biogas plants and bio-fuel production. The

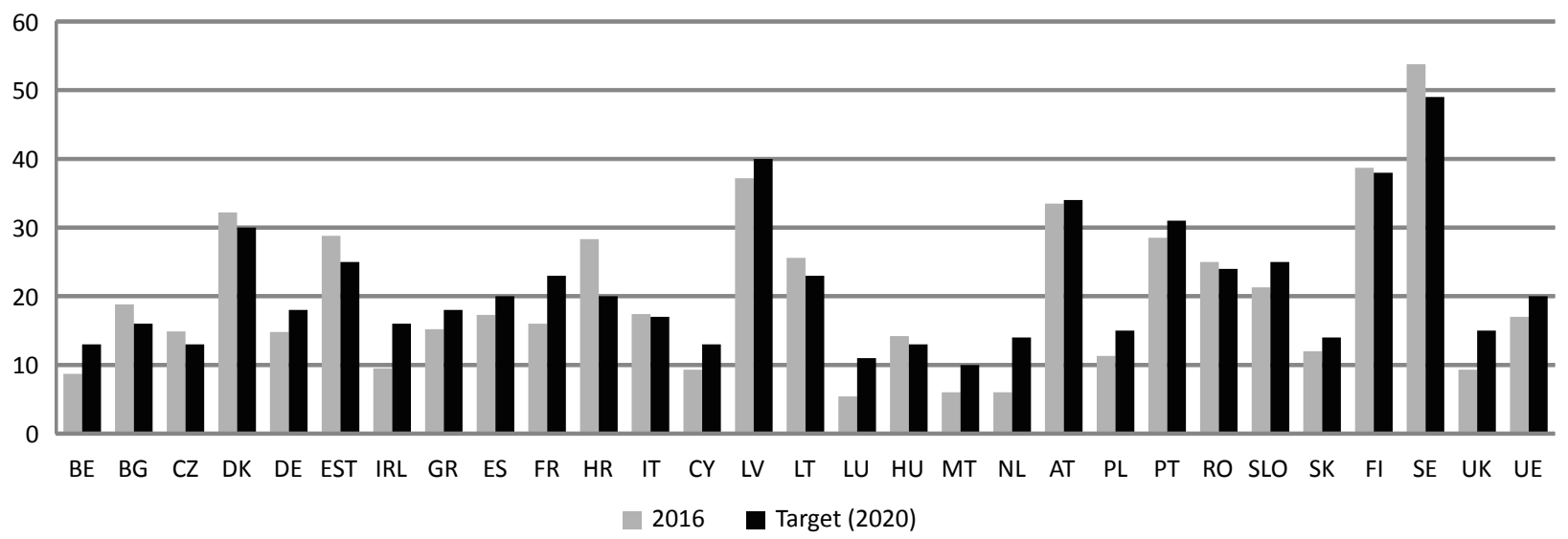

Figure 1. Share of energy from renewable sources in the EU Member States (\% of gross final energy consumption) Source: own study. 
Proceedings of the 2018 International Scientific Conference 'Economic Sciences for Agribusiness and Rural Economy' No 1, Warsaw, 7-8 June 2018, pp. 259-267

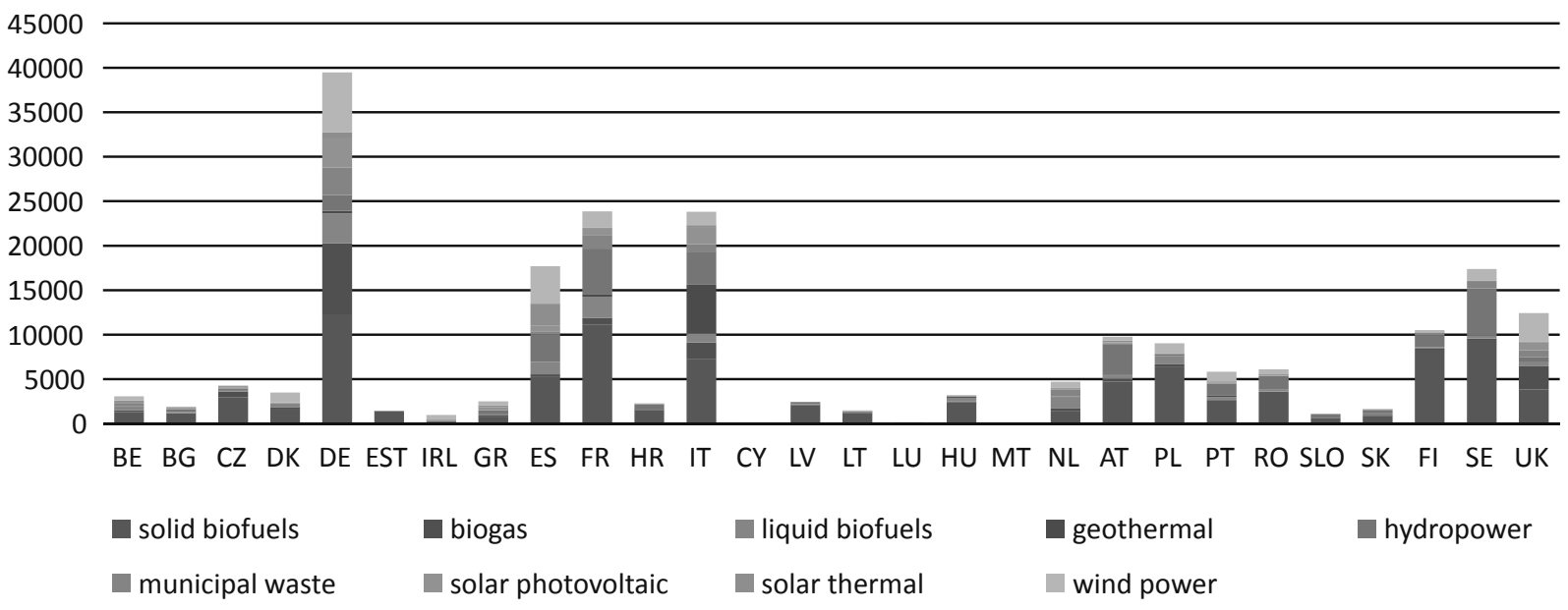

Figure 2. Primary energy production from renewable sources in the EU Member States in 2016 (thous. toe)

Source: own study.

share of biomass in the total RES energy balance varied among the countries - from $14.6 \%$ in Malta and $17.6 \%$ Cyprus to $96.3 \%$ in Estonia, 90.7\% Hungary, 90.6\% Latvia and $84.7 \%$ Poland. However, its share decreased from $67.7 \%$ in 2005 to $59.1 \%$ in 2016 . At the same time, due to subsidies from the funds guaranteed by the countries, wind and solar energy gained importance.
The development of renewable energy sources led to the improved employment - in 2016 it was $1,422.5$ thousand of people: 352.3 thousand in solid biomass, 308.7 thousand in the wind power sector, 250 thousand in heat pumps, 203.6 thousand in the production of biofuels 95.6 thousand in photovoltaic energy, 76.1 thousand in the production of biogas and 75.6 thousand in the hydro power (Fig. 3).

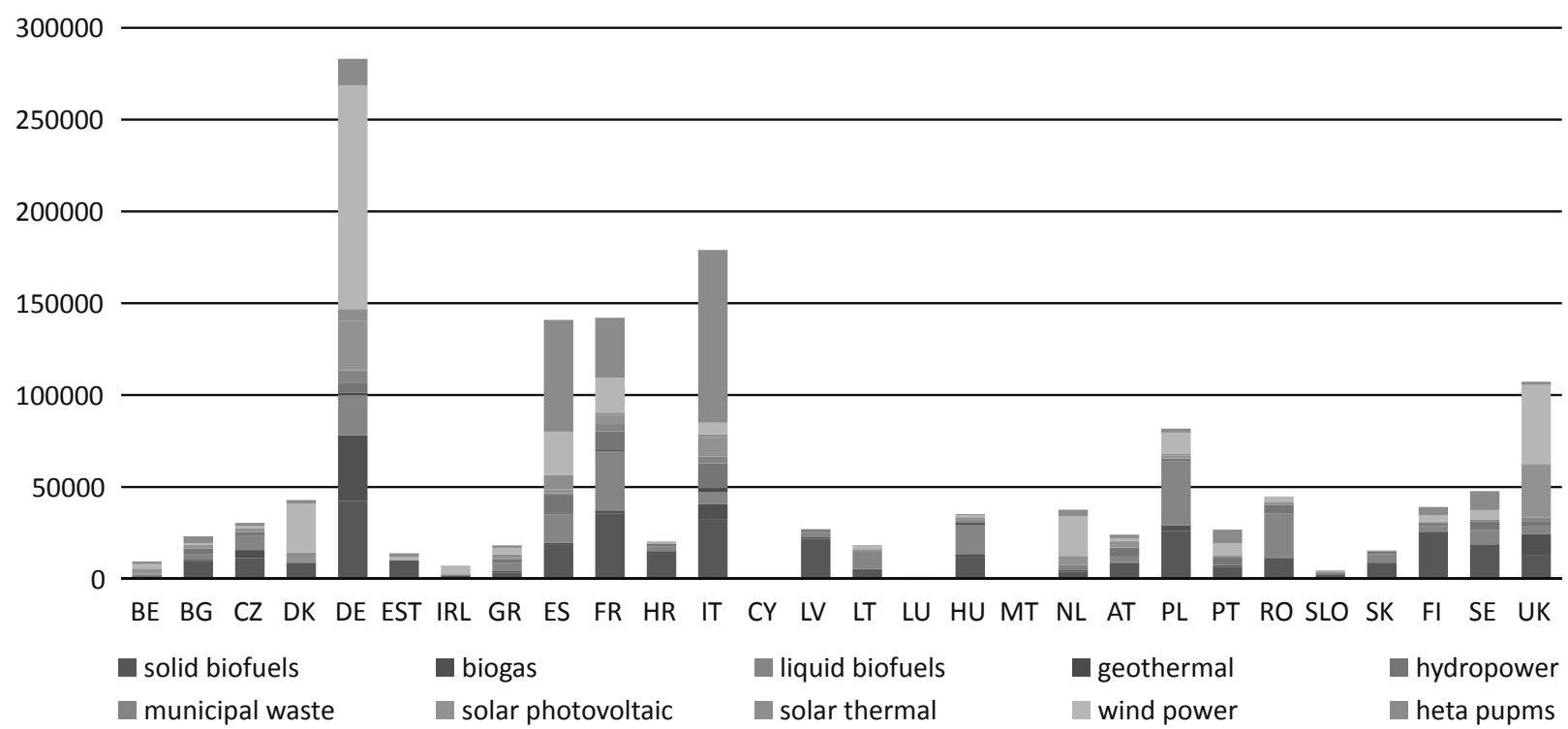

Figure 3. Employment - direct and indirect jobs - by RES sectors in the EU Member States in 2016 Source: own study. 
The data include people working directly in the enterprises operating in the field of producing raw energy materials and energy from renewable sources, as well as providing equipment and services within this field. The number of the employed is correlated with the amount of produced power and the value of investments thus, approximately $30 \%$ of working people is attributed to Germany (284.1 thousand) mainly in wind, photovoltaic and biomass power. In Poland the number was three times smaller, even despite the similar technical potential of RES.

\section{RESULTS}

The conducted research shows that the largest number of working places in relation to generated power appears in the wind, solar and photovoltaic energy sectors (Table 1). A lower amount of produced energy per installed capacity unit in relation to other RES constitutes a key factor influencing such values of employment levels in these sectors. Disproportions are caused by the nature of wind and solar power. In comparison to biogas, these both types of energy may be used only in proper weather conditions, which affects the effective working time of the installed equipment, which is lower than in the case of other renewable energy sources (Gradziuk and Gradziuk, 2017b). Moreover, wind and solar power require the so-called hot backup in the system of power disposition (Żylicz, 2012). Apart from relatively low effective work time, the main reasons for such high employment rates include a dynamic development and innovative character of these sectors. Between 2009 and 2016 , the production of energy through photovoltaic systems increased by $750 \%$, through solar systems - by $326 \%$, through wind systems - by $228 \%$ and through water systems by $4.2 \%$.

The employment does not only differ in terms of various sectors, but they are also characterised by a large variation in terms of time. The highest such difference was observed in the case of photovoltaic, solar, wind and liquid biofuel energy. These sectors are highly innovative and implement the latest scientific and technological solutions. That is why within the analysed period of time a rapid decrease in the employment rate in these sectors was observed. In photovoltaic sector it amounted to 12 times, in solar energy - to 6 times, in wind, biogas and liquid biofuels - by a half. Gostomczyk (2012) obtained similar results, however, in terms of the installed capacity. Research conducted by Heavner and Churchill (2002) suggests that all these changes characterise the investment stage rather than the organisational

Table 1. Number of employees per 1,000 toe of generated energy in RES sectors in 2009-2016

\begin{tabular}{|l|c|c|c|c|c|c|c|c|}
\hline Specification & 2009 & 2010 & 2011 & 2012 & 2013 & 2014 & 2015 & 2016 \\
\hline Hydro power & $0.5^{*}$ & $0.5^{*}$ & $0.8^{*}$ & $0.7^{*}$ & $0.8^{*}$ & $0.8^{*}$ & 3.2 & 2.5 \\
\hline Wind power & 21.5 & 19.7 & 17.9 & 17.2 & 15.4 & 14.9 & 12.2 & 11.9 \\
\hline Solar thermal & 40.9 & 27.6 & 22.1 & 14.4 & 11.5 & 9.9 & 7.1 & 6.6 \\
\hline Solar photovoltaic & 120.8 & 138.4 & 84.8 & 43.6 & 22.4 & 14.9 & 12.9 & 10.6 \\
\hline Solid biofuels & 3.6 & 3.3 & 3.4 & 3.3 & 3.4 & 3.6 & 3.8 & 3.7 \\
\hline Biogas & 7.0 & 6.6 & 6.5 & 5.6 & 4.9 & 4.6 & 4.6 & 4.6 \\
\hline Liquid biofuels & 12.7 & 13.0 & 10.7 & 10.0 & 8.1 & 7.8 & 13.4 & 14.8 \\
\hline Municipal waste & 3.3 & 3.2 & 2.9 & 2.6 & 2.5 & 2.4 & 2.5 & 2.5 \\
\hline Geothermal & 1.8 & 2.0 & 1.7 & 1.9 & 1.9 & 1.9 & 1.7 & 1.6 \\
\hline
\end{tabular}

*Without large hydro power plants.

Source: own study. 
Proceedings of the 2018 International Scientific Conference 'Economic Sciences for Agribusiness and Rural Economy' No 1, Warsaw, 7-8 June 2018, pp. 259-267

one. Sastresa et al. (2010) explain that these processes are caused by automation of RES equipment production, the scale effect and gaining knowledge - they all contribute to gradual decrease of discrepancies concerning employment between the sectors Gostomczyk (2012, 2015).

The relation between the number of the employed and the quantity of obtained primary energy in the given sectors of RES was also determined with the sue of statistics and econometrics. First of all, the analysed variables were statistically characterised (Table 2).

The logarithmised values of observation of the period between 2009 and 2016 collected from $28 \mathrm{Mem}$ - ber States of the EU provided the basis for constructing panel models with fixed effects (Table 3 ). The obtained models are adjusted to the empirical data, the rectified coefficient of determination equalled, depending on the sector, 0.828 (liquid biofuels) to 0.981 (solid biofuels), while for hydro power, solar thermal, solar photovoltaic, liquid biofuels and geothermal the parameters by the explanatory variables turned out to be invalid and equalled up to 0.05 . Presumably, the lack of relevance of these parameters (up to 0.05) was motivated by the fact that the a considerable part of variation $Y$ was caused by the difference between the examined countries - specific fixed effects (see Rho value in Table 3 ).

Table 2. Basic statistics employees $(Y)$ and generated energy $(X)$ in RES sectors

\begin{tabular}{|c|c|c|c|c|c|c|c|c|}
\hline RES sectors & Variable & Min & Q1 & Q2 & Q3 & Max & Skewness & $\begin{array}{c}\text { Normality } \\
\text { test } \\
\text { (P) }\end{array}$ \\
\hline \multirow{2}{*}{ Hydro power } & $Y$ & 0.0 & 23.8 & 331.3 & 1341.3 & 6791.2 & 1.813 & $<0.000001$ \\
\hline & $X$ & 0.0 & 67.3 & 385.0 & 1035.0 & 5100.0 & 1.901 & $<0.000001$ \\
\hline \multirow{2}{*}{ Wind power } & $Y$ & 0.0 & 21.4 & 169.4 & 679.1 & 6823.3 & 2.699 & $<0.000001$ \\
\hline & $X$ & 0.0 & 153.7 & 2061.0 & 6550.0 & 146100.0 & 3.832 & $<0.000001$ \\
\hline \multirow{2}{*}{ Solar thermal } & $\mathrm{Y}$ & 0.0 & 4.5 & 11.9 & 66.2 & 2486.2 & 5.432 & $<0.000001$ \\
\hline & $X$ & 0.0 & 55.9 & 311.0 & 1840.0 & 16100.0 & 2.578 & $<0.000001$ \\
\hline \multirow{2}{*}{ Solar photovoltaic } & $Y$ & 0.0 & 0.5 & 7.6 & 89.7 & 3341.2 & 3.991 & $<0.000001$ \\
\hline & $X$ & 0.0 & 75.1 & 760.0 & 5100.0 & 112600.0 & 3.862 & $<0.000001$ \\
\hline \multirow{2}{*}{ Solid biofuels } & $Y$ & 0.0 & 949.9 & 1491.1 & 4688.1 & 12111.1 & 1.114 & $<0.000001$ \\
\hline & $X$ & 0.0 & 2512.6 & 4220.0 & 13950.0 & 69200.0 & 2.098 & $<0.000001$ \\
\hline \multirow{2}{*}{ Biogas } & $Y$ & 0.0 & 16.9 & 76.9 & 229.0 & 7873.9 & 4.432 & $<0.000001$ \\
\hline & $X$ & 0.0 & 57.1 & 175.0 & 685.0 & 54000.0 & 5.111 & $<0.000001$ \\
\hline \multirow{2}{*}{ Liquid biofuels } & $Y$ & 0.0 & 24.2 & 159.2 & 427.7 & 3611.8 & 2.786 & $<0.000001$ \\
\hline & $X$ & 0.0 & 309.0 & 1240.0 & 5288.0 & 35900.0 & 2.567 & $<0.000001$ \\
\hline \multirow{2}{*}{ Municipal waste } & $Y$ & 0.0 & 0.0 & 46.2 & 471.1 & 3055.2 & 2.936 & $<0.000001$ \\
\hline & $X$ & 0.0 & 0.0 & 55.0 & 620.0 & 7500.0 & 2.514 & $<0.000001$ \\
\hline \multirow{2}{*}{ Geothermal } & $Y$ & 0.0 & 0.0 & 7.1 & 32.9 & 5572.1 & 4.789 & $<0.000001$ \\
\hline & $X$ & 0.0 & 0.0 & 55.0 & 210.0 & 6100.0 & 4.002 & $<0.000001$ \\
\hline
\end{tabular}

Source: own study. 
Proceedings of the 2018 International Scientific Conference 'Economic Sciences for Agribusiness and Rural Economy' No 1, Warsaw, 7-8 June 2018, pp. 259-267

Table 3. Estimated fixed specific effects linear panel models employees $(\ln Y)$ and generated energy $(\ln X)$ in RES sectors

\begin{tabular}{|c|c|c|c|c|c|c|c|}
\hline RES sectors & Variable & Est. & SE & t-Stat. & $\mathrm{P}$ & $\mathrm{R}^{2}$ & Rho \\
\hline \multirow{2}{*}{ Hydro power } & $\ln X$ & -0.27425 & 0.249821 & -1.12 & 0.261 & \multirow{2}{*}{0.836} & \multirow{2}{*}{0.911} \\
\hline & cons. & 7.35712 & 1.434798 & 5.61 & 0.000 & & \\
\hline \multirow{2}{*}{ Wind power } & $\ln X$ & 0.32345 & 0.078054 & 3.52 & 0.000 & \multirow{2}{*}{0.909} & \multirow{2}{*}{0.849} \\
\hline & cons. & 5.97791 & 0.426581 & 14.01 & 0.000 & & \\
\hline \multirow{2}{*}{ Solar thermal } & $\ln X$ & 0.08342 & 0.112893 & 0.85 & 0.453 & \multirow{2}{*}{0.951} & \multirow{2}{*}{0.947} \\
\hline & cons. & 6.03461 & 0.357169 & 17.86 & 0.000 & & \\
\hline \multirow{2}{*}{ Solar photovoltaic } & $\ln X$ & 0.05769 & 0.063201 & 091 & 0.361 & \multirow{2}{*}{0.848} & \multirow{2}{*}{0.837} \\
\hline & cons. & 8.26711 & 0.290578 & 29.61 & 0.000 & & \\
\hline \multirow{2}{*}{ Solid biofuels } & $\ln X$ & 1.61372 & 0.198179 & 8.02 & 0.000 & \multirow{2}{*}{0.981} & \multirow{2}{*}{0.949} \\
\hline & cons. & -3.31567 & 1.495604 & -2.36 & 0.022 & & \\
\hline \multirow{2}{*}{ Biogas } & $\ln X$ & 0.61228 & 0.087961 & 7.11 & 0.000 & \multirow{2}{*}{0.919} & \multirow{2}{*}{0.703} \\
\hline & cons. & 2.95871 & 0.397243 & 7.69 & 0.000 & & \\
\hline \multirow{2}{*}{ Liquid biofuels } & $\ln X$ & -0.16091 & 0.139708 & -1.17 & 0.249 & \multirow{2}{*}{0.828} & \multirow{2}{*}{0.865} \\
\hline & cons. & 8.51963 & 0.794561 & 10.79 & 0.000 & & \\
\hline \multirow{2}{*}{ Municipal waste } & $\ln X$ & 0.41988 & 0.106792 & 3.88 & 0.000 & \multirow{2}{*}{0.906} & \multirow{2}{*}{0.901} \\
\hline & cons. & 3.67816 & 0.538124 & 7.03 & 0.000 & & \\
\hline \multirow{2}{*}{ Geothermal } & $\ln X$ & -0.07456 & 0.162392 & -0.41 & 0.602 & \multirow{2}{*}{0.869} & \multirow{2}{*}{0.902} \\
\hline & cons. & 5.23281 & 0.517811 & 10.12 & 0.000 & & \\
\hline
\end{tabular}

Source: own study.

The flexibility of employment estimated in relation to the primary energy varied greatly among the specified sectors. The greater flexibility was observed in the solid biomass sector $(1.61 \%)$, then the biogas sector $(0.61 \%)$, the municipal waste sector $(0.42 \%)$ and the wind power sector $(0.32 \%)$.

\section{CONCLUSIONS}

Currently, the energy-related policies implemented by the developed countries is characterised by a gradual elimination of the share of traditional non-renewable sources of energy. The stage is taken by the renewable ones. Within the European Union, the production of primary energy from the renewable sources increased by $70 \%$ between 2005 and 2015 , while by 2020 it shall be doubled. The positive impact on the labour market is one of the main arguments for the development of the renewable energy sources. However, the data concerning the number of the employed and the number of working places in these sectors available in the literature on the subject are not coherent. It may be caused by application of various tools of estimation (Henriques, Coelho and Cassidy, 2016), or local and technological factors (Gostomczyk, 2015). The presented results were developed upon the average data concerning the employment and the quantity of produced primary energy. The analysed models show that throughout the examined period, the solar and wind power sectors were the ones that consumed the 
larger amount of work. As it was indicated above, these sectors are considered the most innovative and technologically advanced ones and thus, the employment rates seem to decreased in the shorter time. Hence, it shall be advised to continue the conducted research on examining tendencies of the changes with consideration of the scale of production and the division between the directly and indirectly employed. The preliminary assumptions show that for some sectors it shall be better to apply the linear models, however, it shall be subjected to further analysis.

The labour market in the heat pump sector was also preliminarily recognized. A modern, electrically driven heat pump under optimal operating conditions can easily deliver three to five units of energy for every one unit of energy that it consumes. That incremental energy delivered is considered the renewable portion of the heat pump output. The scale of the heat pump market is difficult to assess due to the lack of data and to inconsistencies among existing datasets. The largest markets for heat pumps are the United States, China and Europe as a whole, where France, Germany, Italy and Sweden were the most significant national markets in 2016. Europe's combined heat pump market (for both air and ground source) grew by about $12 \%$ in 2015 (the most recent year for which data are available), adding 890,000 units for a total of 8.4 million units installed. By the end of 2016, total European installed heat pump capacity reached about $73.6 \mathrm{GWth}$, producing an estimated $148 \mathrm{TWh}$ of useful energy, of which about 94.7 TWh, or 64\%, was derived from ambient air and the ground, and the rest was derived from input energy. Total heat pump employment in the European Union is estimated at 249,400 FTE in 2016 (240,300 in 2015, +4\%). Italy, Spain, France, Germany and Sweden have the highest employment figures resulting from heat pump activities.

\section{REFERENCES}

1. Directive 2009/28/EC of the European Parliament and of the Council of 23 April 2009 on the promotion of the use of energy from renewable sources and amending and subsequently repealing Directives 2001/77/EC and 2003/30/EC. OJ L 140/16 of 05.06.2009.
2. Fraunhofer ISI, Ecofys, EEG, Rütter Soceco Socio -economic Research + Consulting, SEURECO (2014). Employment and growth effects of sustainable energies in the European Union. Final Report. Karlsruhe.

3. European Commission (1997). Energy for the Future: Renewable Sources of Energy. White Paper for a Community Strategy and Action Plan. COM(97) 599 final (26.11.1997).

4. European Commission (2003). Overview Report. Meeting the Targets and Putting Renewables to Work, ALTENER Programme, DG for Transport and Energy. Brussels.

5. European Commission (2011a). Communication from the Commission to the European Parliament, the Council, the European Economic and Social Committee and the Committee of the Regions. A Roadmap for moving to a competitive low carbon economy in 2050, SEC (2011) 289 final.

6. European Commission (2011b). Communication from the Commission to the European Parliament, the Council, the European Economic and Social Committee and the Committee of the Regions. Roadmap to a Resource Efficient Europe, SEC (2011) 1068 final.

7. Gostomczyk, W. (2012). Zróżnicowanie nakładów pracy i kosztów w sektorze odnawialnych źródeł energii [Diversification of labour and costs in the sector of renewable energy sources]. Roczniki SERiA, 15 (4), pp. 122-127.

8. Gostomczyk, W. (2015). Wykorzystanie biomasy energetycznej do kreowania rynku pracy w aspekcie rozwoju zrównoważonego [The use of energy biomass to create the labour market in the aspect of sustainable development]. Wydawnictwo Politechniki Koszalińskiej w Koszalinie, Koszalin.

9. Gradziuk, B., Gradziuk, P. (2017a). The impact of Renewable Energy Production on Employment. Barometr Regionalny. Analizy i Prognozy, 15 (3), pp. 139-146.

10. Gradziuk, P., Gradziuk B. (2017b). An Attempt to Evaluate Absorption of the Funds from the Operational Program Infrastructure and Environment within Action 'Generation of Energy from Renewable Sources'. Barometr Regionalny. Analizy i Prognozy, 15 (1), pp. 7-16.

11. Greenpeace Polska (2011). Pracując dla klimatu. Zielone miejsca pracy w Polsce [Working for the climate. Green jobs in Poland]. Press release of 11th of March.

12. Heavner, B., Churchill, S. (2002). Renewables work. In: Job growth from renewable energy development in California. CALPRG Charitable Trust, Los Angeles. 
13. Henriques, C., Coelho, D., Cassidy, N. (2016). Employment impact assessment of renewable energy targets for electricity generation by 2020 - An IO LCA approach. Sustainable Cities and Society, 26, pp. 519-530 .

14. International Renewable Energy Agency (2016). Renewable capacity statistics. IRENA Headquarters, Masdar City, Abu Dhabi.

15. International Renewable Energy Agency (2018). Renewable energy and jobs. Annual Review. Abu Dhabi.

16. Janssen, R. (2002). Renewable energy into the mainstream. OECD/IEA, Paris.

17. Kammen, D., Kapadia, K., Fripp, M. (2004). Putting renewables to work: how many jobs can the clean energy industry generate? Report. University of California Berkeley.

18. Li, X. (2005). Diversification and localization of energy systems for sustainable development and energy security. Energy Policy, 33, pp. 2237-2243.

19. Moreno, B., Lopez, J. (2008). The effect of renewable energy on employment. The case of Asturia (Spain). Renewable and Sustainable Energy Reviews, 12, p. 11.

20. Ölz, S., Sims, R., Kirchner, N. (2007). Contribution of renewables to energy security. IEA information paper. OECD/IEA, Paris.
21. Research \& Consulting Ltd. (1995). The Potential Contribution of Renewable Energy Schemes to Employment Opportunities. Raport for ETSU.

22. Sastresa, E.L., Uson, A.A., Bribian, I.Z., Scarpellini, S. (2010). Local Impact of Renewables on Employment: Assessment Methodology and Case Study. Renewable \& Sustainable Energy Reviews, 14 (2), pp. 679-690.

23. Schumacher, E. (1981). Małe jest piękne [Small is beautiful]. PIW, Warszawa.

24. Sidorczuk-Pietraszko, E. (2015). Wpływ instalacji odnawialnych źródeł energii na tworzenie miejsc pracy w wymiarze lokalnym [The impact of renewable energy installations on job creation at the local level]. Ekonomia i Środowisko, 3 (54), pp. 26-41.

25. Valentine, S.V. (2011). Emerging symbiosis: renewable energy and energy security. Renewable and Sustainable Energy Reviews, 15 (9), pp. 4572-4578.

26. Żylicz, T. (2012). Ekonomia wobec wspierania odnawialnych źródeł energii [Economics in support of renewable energy sources]. In: Rączka, J., Swora, M., Stawiany, W. (eds.) Generacja rozproszona w nowoczesnej polityce energetycznej - wybrane problemy i wyzwania [Generation dispersed in modern energy policy - selected problems and challenges]. Narodowy Fundusz Ochrony Środowiska i Gospodarki Wodnej, Warszawa, pp. 46-50. 